\title{
Factors affecting the acceptance of people with disabilities at work: a literature review
}

Citation for published version (APA):

Vornholt, K., Uitdewilligen, S., \& Nijhuis, F. J. N. (2013). Factors affecting the acceptance of people with disabilities at work: a literature review. Journal of Occupational Rehabilitation, 23(4), 463-475.

https://doi.org/10.1007/s10926-013-9426-0

Document status and date:

Published: 01/01/2013

DOI:

10.1007/s10926-013-9426-0

Document Version:

Publisher's PDF, also known as Version of record

Document license:

Taverne

Please check the document version of this publication:

- A submitted manuscript is the version of the article upon submission and before peer-review. There can be important differences between the submitted version and the official published version of record.

People interested in the research are advised to contact the author for the final version of the publication, or visit the DOI to the publisher's website.

- The final author version and the galley proof are versions of the publication after peer review.

- The final published version features the final layout of the paper including the volume, issue and page numbers.

Link to publication

\footnotetext{
General rights rights.

- You may freely distribute the URL identifying the publication in the public portal. please follow below link for the End User Agreement:

www.umlib.nl/taverne-license

Take down policy

If you believe that this document breaches copyright please contact us at:

repository@maastrichtuniversity.nl

providing details and we will investigate your claim.
}

Copyright and moral rights for the publications made accessible in the public portal are retained by the authors and/or other copyright owners and it is a condition of accessing publications that users recognise and abide by the legal requirements associated with these

- Users may download and print one copy of any publication from the public portal for the purpose of private study or research.

- You may not further distribute the material or use it for any profit-making activity or commercial gain

If the publication is distributed under the terms of Article $25 \mathrm{fa}$ of the Dutch Copyright Act, indicated by the "Taverne" license above, 


\title{
Factors Affecting the Acceptance of People with Disabilities at Work: A Literature Review
}

\author{
Katharina Vornholt $\cdot$ Sjir Uitdewilligen • \\ Frans J. N. Nijhuis
}

Published online: 12 February 2013

(C) Springer Science+Business Media New York 2013

\begin{abstract}
Purpose A lack of social acceptance by nondisabled co-workers is often the reason why employees with disabilities fail to stay in regular organizations for sustained periods. The aim of the study is to present a coherent review of the extant literature on factors affecting the acceptance of people with disabilities in regular employment. Method We conducted a search of the electronic databases PsychINFO and Web of Science (period: 1996-2011) supplemented with a search for additional relevant articles by means of cross-referencing. In total 48 articles were selected, coded and analyzed by three coders into three overarching themes. Results The analysis of included articles shows that the acceptance of employees with disabilities is influenced by three main variable groups: characteristics of co-workers, of the persons with disabilities and of the employers/organizations. Most studies present factors that influence co-workers' or employers' attitudes toward employees with disabilities such as demographic variables. Conclusion Although, recent research has started to accumulate findings on factors that affect the acceptance of employees with disabilities, many gaps remain in the understanding of the concept of acceptance and its relation to the employment of people with disabilities.
\end{abstract}

Keywords People with disabilities - Employee acceptance $\cdot$ Sustainable employment $\cdot$ Literature review

K. Vornholt $(\bowtie) \cdot S$. Uitdewilligen · F. J. N. Nijhuis

Department of Work and Social Psychology, Maastricht University, P.O. Box 616, 6200 MD Maastricht, The Netherlands

e-mail: katharina.vornholt@maastrichtuniversity.nl

\section{Introduction}

Work can be considered one of the most important activities in people's life [1]. Work is not only needed to earn a living, but also fulfills a number of basic human needs including those for a time structure, a collective purpose, social contact, status, and activity [2], that help to sustain mental health and well-being [3]. Studies have shown that particularly among unemployed people and people who are out of the labor force (people who are not actively seeking paid work or are not available for paid work), deprivation of these factors causes distress [4-7].

For people with disabilities employment is particularly important, because having a disability often means being socially isolated [8-10] and work is one opportunity to reduce this isolation [8-11]. According to the Global Burden of Disease Survey (2004) [12] more than $14 \%$ of the European population of working age (15-59 years) experiences a moderate to severe disability. Disability is a complex concept with multiple dimensions [11]. It is "the umbrella term for impairments, activity limitations and participation restrictions, referring to the negative aspects of the interaction between an individual (with a health condition) and that individual's contextual factors (environmental and personal factors)" [11, p. 4]. Social isolation of people with disabilities is caused by physical barriers to attain social events or, more often, is exclusion created by the non-disabled population [13], including disadvantages on the labor market. According to the World Report on Disability (2011) [11] only $53 \%$ men and $20 \%$ women with disabilities, compared to $65 \%$ non-disabled men and $30 \%$ non-disabled women, are employed. The OECD report Sickness, Disability and Work: Breaking the Barriers (2010) [14] describes the situation similarly: according to their data $44 \%$ of people with disabilities are employed 
compared to $75 \%$ of non-disabled people. Also the number of people who are neither working nor registered as unemployed is about two times higher among persons with disabilities (49 and $20 \%$ respectively) ${ }^{1}[11,14]$.

Although having work is an important condition for reducing isolation, even people with disabilities who are employed, frequently indicate that they feel stigmatized and less included in the group of colleagues than nondisabled employees [15]. Therefore, we pose that simply having a job is not sufficient; social integration into the group of colleagues and acceptance by the colleagues is an essential pre-condition for the beneficial effects of work to become operative. Social psychologists have captured this notion in the belongingness hypothesis, which states that all human beings have a strong motive to obtain positive and lasting interpersonal relationships and interactions with other people [16]. While long-term exposure to negative interpersonal reactions causes poor psychological and physical health, positive reactions of others stimulate psychological and physical well-being [16-19]. As social psychology suggests that acceptance is maybe 'the' most important factor for people's well-being within a social context [20], it is surprising that it never gained a central position in research on people with disabilities at work. In particular, acceptance by colleagues is likely to be important for sustainable employment of people with disabilities. Sustainability implies that employees have the possibility and ability to function on the long term considering achievement and maintenance of participation and health [21]. We consider social integration to be successful when the employee with a disability is accepted as a full member of the group by all colleagues and supervisors. Acceptance is thus an essential component of social integration at work.

In 1996 Stone and Colella developed a model of factors affecting the treatment of individuals with disabilities in organizations [22]. This comprehensive model covers a broad range of factors including environmental, organizational and person factors. According to the model, organizational characteristics and legislation influence the attributes (e.g. demographic characteristics, personality, gender, nature of disability) of the employees with and without disabilities as well as the nature of the jobs (e.g. ability requirements, interdependence, reward system). These factors in turn affect psychological consequences, such as stereotyping or affective states, and job-related expectancies of colleagues regarding the employee with a disability. Expectancies and consequences then determine

\footnotetext{
1 These numbers have to be interpreted carefully as data are inconsistent across countries. Besides different interpretations of the concept disability, the numbers partly include sheltered work or supported employment for those countries that offer these opportunities to people with disabilities.
}

the treatment of the employee with a disability and cause reactions toward this treatment. The present study builds on this model and contributes to it in three ways: (1) we report on research that has been published since the publication of the model in 1996, (2) compared to the theoretical approach of Stone and Colella, we particularly focus on studies that have empirically examined factors of the model, and (3) we specifically zoom in on the concept of acceptance of people with disabilities as a major factor contributing to the integration of people with disabilities at work. The results of this study will be discussed in light of the model.

The purpose of this review is to present a coherent picture of the results of studies about the acceptance of employees with disabilities at work and to identify directions for future studies. Reviews on the relationships between co-workers and people with disabilities that have already been published are generally limited to attitudes toward people with disabilities [23-25], whereas a variety of personal and contextual factors are likely to impact whether an individual with a disability will be accepted by his or her colleagues. An integrative review that presents factors related to the acceptance of employees with disabilities in addition to attitudes is still missing. Our central research question is therefore: Which factors influence the acceptance of people with disabilities in regular employment settings? Instead of aiming to build an overall model of factors related to successful employment of people with disabilities, we explicitly focus this review on factors related to acceptance, thereby highlighting a central concept that has been underrepresented in the existing literature. Before we proceed, we will conceptualize the term acceptance.

\section{Theoretical Background of the Concept "Acceptance"}

To our knowledge, the term "acceptance" has never been clearly defined when it comes to the acceptance of employees with disabilities at work. The UN Convention on the Rights of Persons with Disabilities (2006) states that persons with disabilities have the right to work "on an equal basis with others" [26]. The equivalent in the United States is the Americans with Disabilities Act (ADA 1990) [27]. It recognizes that "physical and mental disabilities in no way diminish a person's right to fully participate in all aspects of society". However, both, the UN charter and the ADA, mostly refer to the organizational or legislative rights of people with disabilities; they prohibit discrimination and protect their rights. They do not give a clear description of what acceptance in the context of employment is. The Developmental Disabilities Assistance and Bill of Rights Act of 2000 [28] is more specific. It states that inclusion is the "the acceptance and encouragement of 
the presence and participation of individuals with [...] disabilities, by individuals without disabilities, in social, educational, work, and community activities, that enables individuals with [...] disabilities to (a) have friendships and relationships with individuals and families of their own choice; (b) live in homes close to community resources, with regular contact with individuals without disabilities in their communities; (c) enjoy full access to and active participation in the same community activities and types of employment as individuals without disabilities; and (d) take full advantage of their integration into the same community resources as individuals without disabilities, living, learning, working, and enjoying life in regular contact with individuals without disabilities" [28]. Likewise, there are several other conventions, rights, and acts (e.g. the Law of the People's Republic of China on the Protection of Disabled Persons or the Disability Discrimination Act in Australia). However, none provides us with a clear definition of the concept acceptance in terms of people with disabilities in employment situations.

Whereas some studies, which we present in this review, refer to the ADA as the standard definition of acceptance, in many others no explicit definition of acceptance of people with disabilities in the work environment is provided. Rather, most researchers use an operational instead of a theoretical definition to describe acceptance. They argue that social integration can be measured as the amount and quality of interactions employees with disabilities have with their non-disabled colleagues. For instance, Gates et al. [29] define a social process by the structure of the relationships (e.g., who someone is in contact with, the frequency of contact, the length of contact) and the quality of the relationship. They further state that the relationships should be based on emotional and informational support, including appraisal or feedback.

Lau and Cheung [30] mention the contact hypothesis which states that familiarity leads to acceptance. Similarly, Cramm et al. [31] argue that integration can be compared to the type of relationship between colleagues. From their perspective, colleagues work well together if a relationship, which can range from "work acquaintance" to "social friends", is the basis of their collaboration, with the latter representing the highest level of integration. McLaughlin et al. [32] conceptualize acceptance in terms of the attitudes employees have toward their colleagues with disabilities, their perceptions of fairness of an accommodation that has been made for the employee with a disability, and the employment judgments they make with respect to hiring, promoting, and retaining an employee with a disability.

The approach to define acceptance in terms of attitudes finds its roots in the work of Fishbein and Ajzen [see 33] and their Theory of Reasoned Action. This theory explains the link between attitudes, intentions, and behavior and underlies our comprehension of the concept acceptance. The Theory of Reasoned Action suggests that a person's behavior is predicted by the attitudes toward this behavior as well as the person's expectations regarding reactions of others when performing the behavior in question [33]. Consistent with this theory, we suggest that acceptance can be understood as an outcome or consequence of attitudes toward people with disabilities; an evaluative response on multiple dimensions. According to traditional social psychology, evaluative responses to attitudes have a cognitive, affective, and behavioral dimension, sometimes referred to as the three components of attitudes [34]. Eagly and Chaiken [34] describe the cognitive dimension as the thoughts and beliefs that people have about a person or object (they call it the attitude object); the affective dimension is referred to as the feelings and emotions that people have concerning the attitude object; and finally, the behavioral dimension consists of people's action in relation to the attitude object.

Applied to the concept of acceptance in employment situations, cognitive acceptance refers to the thoughts and ideas co-workers and supervisors have regarding the employee with a disability. High levels of cognitive acceptance signify that co-workers and supervisors perceive the employee with a disability as a full member of the group, have an understanding of the type of disability, and value the competences the individual with a disability has, but also tolerate the impairments. The affective dimension of acceptance refers to the feelings and emotions co-workers experience regarding the employee with a disability. High levels of affective acceptance signify that colleagues feel no reservation due to the disability of the employee and do not experience more negative emotions while thinking about or interacting with him or her than with other colleagues. Behavioral acceptance includes all reactions and behavior toward an individual with a disability. Thus, under high levels of behavioral acceptance, the individual with a disability has access to all common areas and events and is integrated in professional and social activities of the job. Together, the cognitive, affective, and behavioral dimensions of acceptance make up the concept of social acceptance. According to this definition, an employee with a disability is accepted when he/she is treated as a full member of the work community and colleagues do not expect that this employee meets the standards, but experience the disability as a natural part of the co-worker and reward the performance that this colleague effects.

\section{Method}

Search

In order to answer our research question regarding the factors that influence the acceptance of people with 
disabilities in regular employment settings, we searched the electronic databases PsychINFO and Web of Science, limiting the search to articles published between 1996 and 2011. We used the search terms "employee acceptance", "employee relationship", "employee reaction/response", "socialization", "employee attitude", "stigma", and "inclusive employment/work" in combination with the terms "disabled/disability", "workplace diversity", and "supported employment". This initial search resulted in over 5,000 potential articles covering a broad range of topics. To narrow the output of the search, we first excluded all duplicates and articles irrelevant to the aim of the review. We only selected articles concerning the topic "employees with disabilities" for further investigation, resulting in a set of 147 studies. We then searched the references of these articles to identify additional relevant studies. The final selection of articles was made based on the following criteria: (1) the article was published in English and in a peer-reviewed journal, (2) the article reported either qualitative or quantitative empirical research, and (3) the focus of the research was on factors affecting the acceptance of employees with disabilities.

Based on these criteria 48 articles were selected. The majority of research was carried out in North America (35 studies), while five articles reported research conducted in Europe, four in Asia, and four in Australia and Oceania. The samples of the studies were mixed, including students, employees with disabilities, employers, and staff members of community agencies. The most commonly applied method was a survey design (29 studies), followed by semi-structured or structured interviews (12 studies) and experimental designs (4 studies). Three studies used a workplace mapping technique, which is a method to identify the social relationships employees have at work.

\section{Analysis}

Given the variety of designs and methods used in the selected studies, we exerted a broad approach of analysis based on the grounded theory approach [35]. Grounded theory was used because it allows for a systematic generation of theory from existing data with which we aim to give a global presentation of the empirical research that has been done so far on the acceptance of employees with disabilities. The results of this analysis lead to the development of a descriptive model presenting the factors that influence the acceptance of people with disabilities at work.

We reviewed the 48 selected articles and extracted information on authorship, geographic location of the studies, participant characteristics and number of participants, dependent measures, methodology of the research, hypotheses, and results. Based on the extracted data, three coders independently categorized the results of the studies into overarching themes that represent factors influencing the acceptance of employees with disabilities at work. The results of this categorization process were compared and integrated; disagreements were discussed. Three overarching themes emerged, which were antecedents of cognitive acceptance, stigmatization attitudes, and employer characteristics. An overview of the studies can be found in Table 1.

\section{Types of Research Design}

The quality of the studies is difficult to assess and comparison is hardly possible, because different designs were used and many variables tested. Overall, $60 \%$ of the studies used a survey design, whereof $10 \%$ used telephone surveys and $13 \%$ online surveys. No study used a longitudinal design. Seventy-three percent of the studies provided quantitative data. The number of participants varied from eight to nearly 30,000. Forty percent of the studies included between eight and 100 participants and $48 \%$ between 100 and 500 participants. Forty percent of the studies included people with disabilities themselves as respondents in the research, $25 \%$ of the studies asked students for their opinion, and $21 \%$ included employers in the sample.

\section{Results}

From our initial analysis of the articles, three main themes emerged. First, a part of the studies discussed antecedents of cognitive acceptance-factors that influence and form people's attitudes toward a person with a disability. Second, a number of studies investigated stigmatization attitudes, most often from colleagues at work toward employees with disabilities. Third, there was a group of studies concerning the attitudes and behavior patterns of employers with regard to their role in the process of accepting an employee with a disability. We will use these three themes to structure the presentation of our findings. When an article deals with more than one of the themes, the results will be presented under each heading.

\section{Antecedents of Cognitive Acceptance}

This paragraph presents the results of studies that have addressed the question: What factors impact people's attitudes or stereotypes toward employees with disabilities? The results of the studies are mixed. Particularly regarding general demographic variables of respondents, different studies often report non-consistent or even contradictory results regarding the effects of some factors on the acceptance of employees with disabilities. 
Table 1 Overview of studies included in the analysis

\begin{tabular}{|c|c|c|c|c|c|}
\hline Authors & Location & Sample & $\mathrm{N}$ & Method & Focus \\
\hline Amick III et al. [36] & USA & Patients with carpal tunnel syndrome & 197 & Surveys & $\begin{array}{l}\text { Employer } \\
\text { characteristics }\end{array}$ \\
\hline Angermeyer et al. [37] & Germany & $\begin{array}{l}\text { Patients diagnosed with schizophrenia or } \\
\text { depression }\end{array}$ & 210 & Surveys & $\begin{array}{l}\text { Stigmatization } \\
\text { attitudes }\end{array}$ \\
\hline Banks et al. [38] & USA & $\begin{array}{l}\text { Staff members of agencies offering mental } \\
\text { health vocational programs }\end{array}$ & 243 & Surveys & $\begin{array}{l}\text { Antecedents of } \\
\text { cognitive } \\
\text { acceptance }\end{array}$ \\
\hline Bruyère et al. [39] & USA, UK & Human resource professionals & 1615 & Telephone surveys & $\begin{array}{l}\text { Employer } \\
\text { characteristics }\end{array}$ \\
\hline Burge et al. [40] & Canada & General population & 680 & Telephone surveys & $\begin{array}{l}\text { Stigmatization } \\
\text { attitudes }\end{array}$ \\
\hline Butterworth et al. [41] & USA & $\begin{array}{l}\text { Young employees with developmental } \\
\text { disabilities }\end{array}$ & 8 & $\begin{array}{l}\text { Participant observation, } \\
\text { semi-structured } \\
\text { interviews }\end{array}$ & $\begin{array}{l}\text { Antecedents of } \\
\text { cognitive } \\
\text { acceptance }\end{array}$ \\
\hline Chadsey et al. [42] & USA & Employment specialists & 20 & $\begin{array}{l}\text { Surveys, telephone } \\
\text { interviews }\end{array}$ & $\begin{array}{l}\text { Antecedents of } \\
\text { cognitive } \\
\text { acceptance }\end{array}$ \\
\hline Colella et al. [43] & USA & Students & 87 & Experimental design & $\begin{array}{l}\text { Stigmatization } \\
\text { attitudes }\end{array}$ \\
\hline Colella and Varma [44] & USA & Students & 207 & Experimental design & $\begin{array}{l}\text { Stigmatization } \\
\text { attitudes }\end{array}$ \\
\hline Colella and Varma [45] & USA & $\begin{array}{l}\text { Students, employees with and without } \\
\text { disabilities, supervisors }\end{array}$ & 346 & $\begin{array}{l}\text { Experimental design, } \\
\text { surveys }\end{array}$ & $\begin{array}{l}\text { Antecedents of } \\
\text { cognitive } \\
\text { acceptance }\end{array}$ \\
\hline Cramm et al. [31] & Netherlands & Colleagues of supported employees & 36 & $\begin{array}{l}\text { Document analysis, } \\
\text { semi-structured } \\
\text { interviews }\end{array}$ & $\begin{array}{l}\text { Antecedents of } \\
\text { cognitive } \\
\text { acceptance }\end{array}$ \\
\hline Fillary and Pernice [46] & New Zeeland & Employers, supported employees, employees & 24 & $\begin{array}{l}\text { Semi-structured } \\
\text { interviews }\end{array}$ & $\begin{array}{l}\text { Antecedents of } \\
\text { cognitive } \\
\text { acceptance }\end{array}$ \\
\hline García et al. [47] & USA & Students & 114 & Surveys & $\begin{array}{l}\text { Antecedents of } \\
\text { cognitive } \\
\text { acceptance }\end{array}$ \\
\hline Gates et al. [29] & USA & Employees with psychiatric disabilities & 25 & $\begin{array}{l}\text { Workplace mapping } \\
\text { technique }\end{array}$ & $\begin{array}{l}\text { Antecedents of } \\
\text { cognitive } \\
\text { acceptance }\end{array}$ \\
\hline Gilbride et al. [48] & USA & $\begin{array}{l}\text { Employers, employees with disabilities, } \\
\text { rehabilitation placement professionals }\end{array}$ & 68 & $\begin{array}{l}\text { Focus groups, } \\
\text { interviews }\end{array}$ & $\begin{array}{l}\text { Employer } \\
\text { characteristics }\end{array}$ \\
\hline Habeck et al. [49] & USA & Employers & 95 & Online surveys & $\begin{array}{l}\text { Employer } \\
\text { characteristics }\end{array}$ \\
\hline Hand and Tryssenaar [50] & Canada & Employers & 58 & Interviews, surveys & $\begin{array}{l}\text { Employer } \\
\text { characteristics }\end{array}$ \\
\hline Harlan and Robert [51] & USA & Employees with various forms of disabilities & 50 & Structured interviews & $\begin{array}{l}\text { Employer } \\
\text { characteristics }\end{array}$ \\
\hline Hartnett et al. [52] & USA & Employers & 387 & Telephone surveys & $\begin{array}{l}\text { Employer } \\
\text { characteristics }\end{array}$ \\
\hline Henry et al. [53] & USA & $\begin{array}{l}\text { Staff members of community living programs, } \\
\text { students }\end{array}$ & 492 & Online surveys, surveys & $\begin{array}{l}\text { Stigmatization } \\
\text { attitudes }\end{array}$ \\
\hline Henry et al. [54] & USA, Israel & Staff members of community agencies & 221 & Online surveys, surveys & $\begin{array}{l}\text { Stigmatization } \\
\text { attitudes }\end{array}$ \\
\hline Honey [55] & Australia & Consumers of mental health services & 41 & $\begin{array}{l}\text { Focus groups, } \\
\text { interviews, telephone } \\
\text { interviews }\end{array}$ & $\begin{array}{l}\text { Employer } \\
\text { characteristics }\end{array}$ \\
\hline Horner-Johnson et al. [56] & Japan & Students & 275 & Surveys & $\begin{array}{l}\text { Stigmatization } \\
\text { attitudes }\end{array}$ \\
\hline Jones et al. [57] & Canada & Staff members of community agencies & 241 & Surveys & $\begin{array}{l}\text { Stigmatization } \\
\text { attitudes }\end{array}$ \\
\hline
\end{tabular}


Table 1 continued

\begin{tabular}{|c|c|c|c|c|c|}
\hline Authors & Location & Sample & $\mathrm{N}$ & Method & Focus \\
\hline Kaye et al. [58] & USA & Employers & 463 & Surveys & $\begin{array}{l}\text { Employer } \\
\text { characteristics }\end{array}$ \\
\hline $\begin{array}{l}\text { Kulkarni and Lengnick-Hall } \\
\text { [59] }\end{array}$ & India & Employees with disabilities & 31 & Interviews & $\begin{array}{l}\text { Antecedents of } \\
\text { cognitive } \\
\text { acceptance }\end{array}$ \\
\hline Lau and Cheung [30] & China & General population & 822 & Telephone surveys & $\begin{array}{l}\text { Stigmatization } \\
\text { attitudes }\end{array}$ \\
\hline Martz [60] & Russia & Individuals with disabilities & 316 & Surveys & $\begin{array}{l}\text { Employer } \\
\text { characteristics }\end{array}$ \\
\hline McLaughlin et al. [32] & USA & Students & 643 & Surveys & $\begin{array}{l}\text { Antecedents of } \\
\text { cognitive } \\
\text { acceptance }\end{array}$ \\
\hline Morgan and Alexander [61] & USA & Employers & 534 & Surveys & $\begin{array}{l}\text { Employer } \\
\text { characteristics }\end{array}$ \\
\hline Novak et al. [62] & USA & $\begin{array}{l}\text { Employment specialists, employees with } \\
\text { intellectual disabilities }\end{array}$ & 12 & $\begin{array}{l}\text { Semi-structured } \\
\text { interviews, } \\
\text { participant } \\
\text { observations }\end{array}$ & $\begin{array}{l}\text { Antecedents of } \\
\text { cognitive } \\
\text { acceptance }\end{array}$ \\
\hline Ouellette-Kuntz et al. [63] & Canada & Senior psychiatry residents & 58 & Surveys & $\begin{array}{l}\text { Stigmatization } \\
\text { attitudes }\end{array}$ \\
\hline Paetzold et al. [64] & USA & Students & 135 & Experimental design & $\begin{array}{l}\text { Stigmatization } \\
\text { attitudes }\end{array}$ \\
\hline Popovich et al. [65] & USA & Students & 265 & Surveys & $\begin{array}{l}\text { Stigmatization } \\
\text { attitudes }\end{array}$ \\
\hline Rollins et al. [66] & USA & Employees with severe mental illness & 100 & $\begin{array}{l}\text { Workplace mapping } \\
\text { technique }\end{array}$ & $\begin{array}{l}\text { Antecedents of } \\
\text { cognitive } \\
\text { acceptance }\end{array}$ \\
\hline Rollins et al. [67] & USA & Employees with schizophrenia & 104 & $\begin{array}{l}\text { Workplace mapping } \\
\text { technique }\end{array}$ & $\begin{array}{l}\text { Antecedents of } \\
\text { cognitive } \\
\text { acceptance }\end{array}$ \\
\hline Ross [68] & Australia & Students & 200 & Surveys & $\begin{array}{l}\text { Stigmatization } \\
\text { attitudes }\end{array}$ \\
\hline Russinova et al. [69] & USA & Employees with severe mental illness & 436 & Surveys & $\begin{array}{l}\text { Stigmatization } \\
\text { attitudes }\end{array}$ \\
\hline Scheid [70] & USA & Employers & 117 & Telephone surveys & $\begin{array}{l}\text { Stigmatization } \\
\text { attitudes }\end{array}$ \\
\hline Scherbaum et al. [71] & USA & Students & 86 & Online surveys & $\begin{array}{l}\text { Stigmatization } \\
\text { attitudes }\end{array}$ \\
\hline Schur et al. [72] & USA & Employees with and without disabilities & 29897 & Surveys & $\begin{array}{l}\text { Antecedents of } \\
\text { cognitive } \\
\text { acceptance }\end{array}$ \\
\hline $\begin{array}{l}\text { Schwartz and Armony-Sivan } \\
\text { [73] }\end{array}$ & Israel & Students & 149 & Surveys & $\begin{array}{l}\text { Stigmatization } \\
\text { attitudes }\end{array}$ \\
\hline Solovieva et al. [74] & USA & Employers & 194 & Online surveys & $\begin{array}{l}\text { Employer } \\
\text { characteristics }\end{array}$ \\
\hline Varekamp and van Dijk [75] & Netherlands & $\begin{array}{l}\text { Employees with a chronic physical medical } \\
\text { condition }\end{array}$ & 122 & Online surveys & $\begin{array}{l}\text { Employer } \\
\text { characteristics }\end{array}$ \\
\hline Vilà et al. [76] & Spain & $\begin{array}{l}\text { Professionals of job agencies for persons with } \\
\text { disabilities }\end{array}$ & 32 & Focus groups & $\begin{array}{l}\text { Antecedents of } \\
\text { cognitive } \\
\text { acceptance }\end{array}$ \\
\hline Westmorland et al. [77] & Canada & Employees with disabilities & 58 & $\begin{array}{l}\text { Focus groups, } \\
\text { telephone interviews }\end{array}$ & $\begin{array}{l}\text { Employer } \\
\text { characteristics }\end{array}$ \\
\hline Williams-Whitt [78] & Canada & $\begin{array}{l}\text { Managers, union representatives, occupational } \\
\text { health workers, employees with disabilities }\end{array}$ & 22 & $\begin{array}{l}\text { Document analysis, } \\
\text { interviews }\end{array}$ & $\begin{array}{l}\text { Employer } \\
\text { characteristics }\end{array}$ \\
\hline Yazbeck et al. [79] & Australia & $\begin{array}{l}\text { Students, disability service professionals, } \\
\text { general population }\end{array}$ & 492 & Surveys & $\begin{array}{l}\text { Stigmatization } \\
\text { attitudes }\end{array}$ \\
\hline
\end{tabular}


One factor on which these studies report mixed effects is the gender of the respondent. While five studies present a significant effect of gender on acceptance [30, 40, 57, 63, 65] one study finds no effect at all [32]. Jones et al. [57] report that men were more likely to believe that individuals with an intellectual disability do not need to make choices about the things they do each day and that they do not have goals for their lives. In general, if gender effects were found, men were more discriminatory toward employees with disabilities than were women [40, 57, 63, 65]. Just one study conducted in Asia found the reverse effect in that women showed more discriminatory behavior toward people with disabilities than did men [30].

For the factors age and education also no clear conclusion can be drawn from the results of the research conducted up until today. Generally, just five studies found effects of age and education on acceptance [30, 40, 54, 57, 79]. Those respondents with lower levels of education favored the segregation of individuals with disabilities above their integration into society and employment [40, $54,57]$. If effects of age were found, younger people held more positive attitudes than did older people [30, 57, 79].

Five studies investigated the effect of the respondents' career on acceptance [53, 56, 57, 73, 79]. Community agency staff and students in social work and psychology held more favorable attitudes toward individuals with disabilities than the general population [56, 73, 79]. Also individuals with prior knowledge about disabilities or who had experience and regular contact with colleagues with disabilities held more favorable attitudes than did the general population [30, 71, 79].

According to García et al. [47] the personality traits agreeableness and openness to experience affect the appropriateness judgments for accommodations made for employees with disabilities. Colleagues high in agreeableness and openness to experience are more accepting of accommodations made for the employee with a disability than those who score low on these dimensions [47].

Some of the studies indicate that not only characteristics of colleagues, but also factors related to the persons with disabilities themselves and organizational factors are predictive of integration outcomes and acceptance of an employee with a disability. Four studies found an effect of the nature of the disability on acceptance [30, 32, 38, 47]. For example, Banks et al. [38] report that individuals diagnosed with a mood disorder experienced a higher level of integration compared to individuals diagnosed with schizophrenia. However, other types of disabilities were not specified in this study. McLaughlin et al. [32] discovered that disability type has an indirect influence on acceptance. They found that this effect is mediated by stigma, with severity and controllability of the disability as more negatively related to acceptance than other stigma dimensions. Lau und Cheung [30] report that people with mental health difficulties experience more discrimination than those with an intellectual disability.

Another factor that was found to have an effect on acceptance is the performance of the employee with a disability at the workplace [32, 38, 69]. McLaughlin et al. [32] and Banks et al. [38] found that performance significantly influences the acceptance of employees with disabilities. The better the performance of the employee with a disability, the more likely the employee will be socially accepted. Other factors that seem to have an effect on acceptance are the social behavior, communication ability, and hygiene of the individual with a disability [31, 76]. Colella and Varma [45] discovered that individuals with disabilities engaging in ingratiation behavior had significantly better relationships with their supervisors than individuals scoring low on this dimension.

Finally, several organizational factors have been found to have an effect on acceptance. A study by Butterworth et al. [41] reports that interdependence of work tasks significantly enhances the acceptance of employees with disabilities. Furthermore, employees with disabilities are more accepted if they have the same amount of responsibility as other employees and if they work full-time [46, 62]. Additionally, it appears to be beneficial for the acceptance of new employees with disabilities if other employees with disabilities are working in the company already [59]. The results for the effect of the size of a work team on acceptance are mixed. Cramm et al. [31] report that the communication between employees with and without disabilities is better in smaller teams, whereas Gates et al. [29] show that the amount of informational support and feedback, which team members with disabilities receive, is higher in larger teams.

\section{Stigmatization Attitudes}

The above mentioned factors influence the attitudes colleagues have toward their co-workers with disabilities. This paragraph describes the attitudes themselves and how they are expressed. The analysis of the articles presented under this heading reveals that many people have a biased view of the capacities of employees with disabilities. They often perceive employees with disabilities to function at a moderate to severe range of disability and also report that they feel a high degree of social distance toward these employees [40, 68, 70]. Individuals who believe that a coworker with a disability is responsible for increased jobdifficulty and a higher workload have lower expectations toward this co-worker and consequently more negative reactions and attitudes toward employees with disabilities in general [40, 71]. Burge et al. [40] found that in many people's perception an unskilled job together with colleagues without disabilities is considered to be the best type 
of employment for adults with disabilities. Generally, people often seem to have a biased idea of the performance of people with disabilities and, as a consequence, react negatively when it comes to working with co-workers with disabilities. Interestingly, Colella and her colleagues [43, 44] showed that participants in their studies were able to rate the performance of a person with a disability objectively when performance information was directly available. However, when these participants had to predict future performance of an employee with a disability, the two studies revealed contradictory results. While in the first study participants expected future performance to be equal to current performance [43], raters in the second study rather relied upon their stereotypes about disability job-fit for predicting future performance and were therefore less willing to recommend an individual with a disability for promotion [44]. Negative biases were also found to be prevalent under conditions in which the performance of the employee with a disability had direct consequences for the rater (e.g. for receiving a reward) [43].

Other researchers investigated the fairness perceptions of accommodating co-workers with disabilities. Their results show that accommodations especially made for a co-worker with a disability are often seen as unfair and can eventually lead to less acceptance of the employee with a disability [64]. Paetzold et al. [64] additionally found a correlation between an accommodation and the performance of the employee with a disability. They demonstrate that fairness perceptions were lowest when the person with a disability received an accommodation and excelled in performance.

Finally, not only the colleagues, but also employees with disabilities themselves can be biased in their perceptions. Angermeyer et al. [37] found that individuals with disabilities anticipate stigmatization more frequently than they actually experience stigmatization, particularly concerning access to work.

\section{Employer Characteristics}

Employers have an important role in the socialization process of individuals with disabilities. They represent the organizational culture and serve as a model for the employees. Gilbride et al. [48] report several characteristics of employers who are open to hiring people with disabilities. These characteristics include work cultural issues, job match issues, and employer experience and support issues. Cultural issues are the openness of the employers to diversity and the equal treatment of disabled and non-disabled employees, job match issues are for example the focus on the capabilities of an employee instead of on the impairments, and employer experience and support issues are the ability of the employer to manage and supervise a diverse workforce. Schur et al. [72] confirm with their study the beneficial effects of a corporate culture on the integration of employees with disabilities. In general, employers with experience in hiring individuals with disabilities are more likely to come up with advantages to employing individuals with disabilities when asked and are more likely to hire someone with a disability again than inexperienced employers [61].

However, other studies found that many employers have a rather negative attitude toward employees with disabilities $[51,70]$. Because they have concerns about the costs of accommodations and fear the legal liability [58], they in fact avoid the integration of people with disabilities or resist making reasonable accommodations. Harlan and Robert [51] acknowledge that employers often do not make the necessary accommodations for an individual with a disability to become a successful employee. Tactics of resistance used by employers are denying the need for accommodation, renouncing responsibility for providing it, withholding information about legal rights, denying requests, and using intimidation and fear to force individuals to assume responsibility for fitting into the organization [51]. Williams-Whitt [78] reports that there are four impediments to disability accommodation concerning the employer. In her study she features that these impediments are managerial biases, exclusion of the disabled employee from planning an appropriate accommodation, accommodation investigation errors (e.g. problems with balancing illness legitimacy and confidentiality requirements), and strained union-management relations. Besides concerns about costs and legal liability of accommodations requests, employers have safety concerns when it comes to hiring a person with a disability $[50,61]$. These concerns are likely to originate from stereotypes or stigmas employers hold regarding employees with disabilities.

Hartnett et al. [52] indicate that if employers are willing to accommodate employees with disabilities, they benefit from it. These benefits include the ability to retain quality employees in the company, an increase in company profitability, workforce diversity, and avoidance of costs associated with hiring and training new employees [49, 52, 61]. Furthermore, providing accommodation can improve the organizational climate and culture. Solovieva et al. [74] report a number of indirect benefits from making workplace accommodations, including improved interactions with co-workers, increased overall company morale, and increased overall company productivity.

Besides reluctance from employers to commit to hiring, people with disabilities face several other problems when entering the workforce, which can impede their integration into the work environment. Martz [60] found that the most often reported barriers were physical barriers, attitudinal barriers, lack of facilities, and policy barriers. Additionally, employees with disabilities may face psychosocial 
problems, such as work-home interference and a lack of acceptance of the chronic disease [75]. Performing and finishing work tasks as well as social relationships with supervisors or colleagues are sometimes experienced as problematic [67, 75]. Similarly, Honey [55] states that mental illness affects the employees' experience of employment in three areas: the need to maintain mental health, difficulties with work performance, and work confidence and work goals. Some of these problems can be solved by work accommodations. The most often reported and preferred workplace accommodations were time flexibility, working fewer hours, and working from home [39, $74,75]$. The participants in the study of Westmorland et al. [77] specify that disability management practices and procedures are at the core of positive integration outcomes for employees with disabilities. They highlight the need for job accommodation, the importance of open and clear communication, the need of retaining ones job, and the provision of ergonomic modifications. Research of Amick III et al. [36] adds people-oriented culture and safety climate to this list of factors.

\section{Discussion}

Research in the field of work- and organizational psychology concerning the integration of people with disabilities in the regular job market is a recent discipline. Only a limited number of studies have been published, with the scientific quality sometimes being imperfect, and theoretical models or general theories are rare. Comparison between the data that have been gathered to date is problematic, because of the variety of designs and variables that have been used. Standardization in the definitions and operationalization of the main concepts as well as replication of studies is required to validate the results and build a more robust body of knowledge. Moreover, a lack of experimental studies precludes us from drawing conclusions about causality and longitudinal studies that track the development of the relevant constructs over time are missing. Therefore, the research that has been conducted to date gives just a snap-shot of the current situation of employees with disabilities and not yet a complete picture of their integration in regular employment.

However, despite these shortcomings, the findings of the studies concerning the acceptance of employees with disabilities in the workplace do point to some important aspects of the employment situation of people with disabilities. In general, few people with moderate to severe ranges of disability are employed in regular work [11, 14]. This review spots several reasons for this mismatch.

Seven studies, included in this review, show that both employees and employers have biased or even wrong perceptions of people with disabilities at work [40, 43, 44, $50,61,68,70]$. These biases refer to the performance of employees with disabilities, but also to their social skills. People underestimate the capacities of their disabled peers and some respondents in the studies presented in this review even suggest separated workplaces. Moreover, respondents indicated that they feel a social distance to people with disabilities in general and prefer not to share a workplace with them $[40,68,70]$. However, Colella et al. $[43,44]$ demonstrate that participants were able to rate the performance of an individual with a disability accurately when performance information was directly available. In practice though objective information might not always be available and it is therefore more likely that colleagues and supervisors rely upon their stereotypes and biases when evaluating the performance of an employee with a disability.

Several reasons are presented in this review that might cause these negative attitudes toward employees with disabilities. Some studies found effects for respondents' gender, age, and education with a male, old(er), and lowly educated person expressing the most negative attitudes and a female, young, and highly educated person experiencing the least social distance to people with disabilities [40,57]. However, the results of the studies are mixed and further research has to clarify the correlation between these factors and attitudes toward people with disabilities. More distinct is the relation between career and attitudes. Respondents working in community agencies, social work, or psychology generally held more favorable attitudes toward people with disabilities than the general population [56, 73, 79]. One possible explanation for these findings is that the former are likely to have had more regular contact with and possess more extensive knowledge about people with disabilities. Accordingly, a lack of knowledge about the impairments, but mainly about the competences of people with disabilities, seems to be the strongest barrier for the acceptance of people with disabilities in the workplace.

2The same holds for many employers. They experience the employment of people with disabilities as a risk and therefore often refrain from employing a person with a disability $[50,61,70]$. They furthermore resist making reasonable accommodations and thus avoid the integration of people with disabilities within the group of colleagues [48, 51, 70]. Possible reasons for the denial of reasonable accommodations are concerns about costs, safety, fear of legal liability, or managerial biases [50, 58, 61, 78]. But there are also studies that identify characteristics of employers who are open to hiring people with disabilities. These employers are characterized by openness to diversity and the equal treatment of their employees regardless of health conditions. Furthermore, they support the competences of all employees instead of trying to avoid impairments [48, 52]. 
Generally, the results of the studies presented in this review show that there are many factors that influence the acceptance and integration of people with disabilities in the workplace. To summarize the results of the studies so far and visualize our concept of the term acceptance, we developed a descriptive model (see Fig. 1).

\section{Integrative Framework}

The model illustrates the factors that lead to the acceptance of colleagues with disabilities and the connection between these factors. Factors are both directly connected to acceptance or mediated by the attitudes of colleagues. The organization and the employer influence the attitudes of colleagues by organizational values and management style. The attitudes of colleagues are also influenced by factors such as age, education, and gender, which are referred to as the characteristics of colleagues. Finally, attitudes of colleagues are influenced by people with disabilities themselves. Research found that the nature of disability has the strongest impact on colleagues' attitudes in this category. The attitudes of colleagues then form the basis for an integrative work environment and the acceptance of colleagues with disabilities.

We furthermore expect that an organization or employer directly influences the acceptance, and with this the integration, of employees with disabilities; for example through the employment of more than one person with a disability. Research has shown that the integration of a person with a disability is more often successful when there are already employees with disabilities in the company [42, 59]. We also expect that the characteristics of an employee with a disability, such as abilities or personality, can have a direct influence on integration outcomes. However, data are still missing in this field of research.
Finally, we anticipate that the acceptance by colleagues has an effect on a variety of work outcomes for the employees with disabilities such as motivation, satisfaction, quality of life, and self esteem. Studies have shown that employment in general has an effect on these factors $[80,81]$. Based on the findings presented in this review, however, we expect that these positive effects of work can only be achieved through the acceptance of colleagues and the integration into the group of colleagues, although an empirical test of this idea is still missing.

The model we created based on the review of empirical research articles resembles the one Stone and Colella designed in 1996 [22]. Both models recognize organizational as well as individual factors to be important predictors of the integration of people with disabilities at work. While Stone and Colella also take environmental factors such as legislation into account, our model specifies the concept of the attitudes of colleagues and its relationship to the acceptance of employees with disabilities. Stone and Colella assume that organizational factors influence the attributes of the individual with a disability, the attributes of the observers (coworkers and supervisors), and the nature of the job. These three factors then influence the psychological consequences for observers; which finally impact the treatment of the individual with a disability in the organization. The model presented in this review highlights the specific role of the attitudes of co-workers toward employees with disabilities and the relationship of these attitudes to the acceptance of these employees. So, we contribute to the model of Stone and Colella by backing it up with the most recent results of empirical research and by introducing acceptance with its cognitive, behavioral, and affective dimensions as a central variable that mediates between attributes of people with disabilities, co-workers, and employers and the consequences for employees with disabilities.

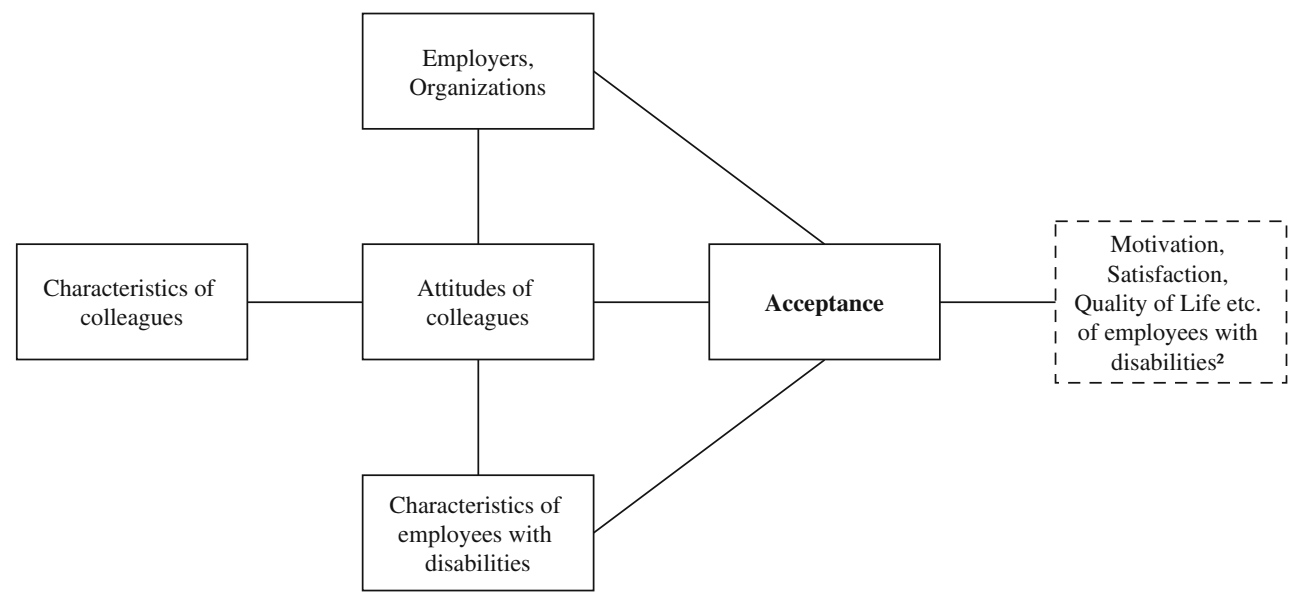

${ }^{2}$ Refers to factors that have not been part of studies so far.

Fig. 1 Descriptive model of factors influencing the acceptance of people with disabilities at work 
The model provides a number of implications for future research. Various links between the factors have not yet been fully investigated and directions of causality still need to be established. Moreover, whereas most studies focus on the cognitive aspects of acceptance, there is a lack of research on behavioral and affective aspects. Finally, as the reported studies are exclusively cross-sectional, longitudinal studies that track the development of acceptance over time can provide a more complete picture of the trajectory of integration of people with disabilities into regular employment.

\section{Limitations}

In this paper we have evaluated the results of research to date on factors affecting the acceptance of people with disabilities at work. The lack of consistency and clarity in the definition of the concept of acceptance in the existing literature precluded us from systematically selecting studies based on search terms, hence we took a more explorative and integrative approach in which we individually selected studies and used extensive cross-referencing for building the sample of studies included in this review. In addition, we limited the search to papers published in English which may exclude considerations of non-English speaking countries. Accordingly, it is possible that not all relevant papers have been included in this review.

Finally, the model presented in this paper is based on a combination of results of the studies presented in the review and more general theoretical work on the concept of acceptance. Therefore, it is as yet untested and needs further investigation to prove its significance.

\section{Conclusion}

Employment is not a universal remedy for the problems that people with disabilities experience. But it is one way to gain access to social contacts and status and to attain a sense of purpose. Work enables participation in society. However, being accepted at work seems to be a necessary condition for employment to become sustainable. Besides societal advantages of being accepted, there are several personal gains of feeling accepted as for example the development of a positive self-perception and general life satisfaction. Acceptance with all its facets seems to be a cornerstone for the long-term integration of people with disabilities at work. What remains is to fill in the gaps to fully understand the concept of acceptance and how it is related to sustainable employment of people with disabilities.

Acknowledgments This research has been funded by the Atlant group, an organization for sheltered and supported employment.
Conflict of interest None.

\section{References}

1. Landy FJ, Conte JM. Work in the 21st century: an introduction to industrial and organizational psychology. 2nd ed. Malden: Blackwell; 2007.

2. Jahoda M. Work, employment, and unemployment: values, theories, and approaches in social research. Am Psychol. 1981;36(2): 184-91.

3. Paul KI, Batinic B. The need for work: Jahoda's latent functions of employment in a representative sample of the German population. J Organ Behav. 2010;31(1):45-64.

4. Paul KI, Geithner E, Moser K. Latent deprivation among people who are employed, unemployed, or out of the labor force. J Psychol. 2009;143(5):477-91.

5. Hoare PN, Machin MA. Maintaining wellbeing during unemployment. Aust J Career Dev. 2006;15(1):19-27.

6. Wanberg CR, Griffiths RF, Gavin MB. Time structure and unemployment: a longitudinal investigation. J Occup Organ Psych. 1997;70:75-95.

7. Creed PA, Evans BM. Personality, well-being and deprivation theory. Pers Indiv Differ. 2002;33(7):1045-54.

8. Hall E. Spaces of social inclusion and belonging for people with intellectual disabilities. J Intell Disabil Res. 2010;54(Suppl 1):48-57.

9. Isaac R, Dharma Raja BW, Ravanan MP. Integrating people with disabilities: their right—our responsibility. Disabil Soc. 2010; 25(5):627-30.

10. O'Grady A, Pleasence P, Balmer NJ, Buck A, Genn H. Disability, social exclusion and the consequential experience of justiciable problems. Disabil Soc. 2004;19(3):259-71.

11. World Health Organization. World report on disability. Geneva: World Health Organization; 2011.

12. World Health Organization. The global burden of disease: 2004 update. Geneva: World Health Organization; 2004.

13. Antonak RF, Livneh H. Measurement of attitudes towards persons with disabilities. Disabil Rehabil. 2000;22(5):211-24.

14. OECD. Sickness, disability and work: breaking the barriers. Paris: OECD; 2010.

15. Hall E. Social geographies of learning disability: narratives of exclusion and inclusion. Area.(2004); doi:10.1111/j.0004-0894. 2004.00227.x.

16. Baumeister RF, Leary MR. The need to belong: desire for interpersonal attachments as a fundamental human motivation. Psychol Bull. 1995;117(3):497-529.

17. Richman LS, Leary MR. Reactions to discrimination, stigmatization, ostracism, and other forms of interpersonal rejection: a multimotive model. Psychol Rev. 2009;116(2):365-83.

18. Thau S, Aquino K, Poortvliet PM. Self-defeating behaviors in organizations: the relationship between thwarted belonging and interpersonal work behaviors. J Appl Psychol. 2007;92(3):840-7.

19. Wu LZ, Yim FHK, Kwan HK, Zhang XM. Coping with workplace ostracism: the roles of ingratiation and political skill in employee psychological distress. J Manage Stud. 2012;49(1): 178-99.

20. DeWall CN, Bushman BJ. Social acceptance and rejection: the sweet and the bitter. Curr Dir Psychol Sci. 2011;20(4):256-60.

21. van der Klink JJL, Bültmann U, Brouwer S, Burdorf A, Schaufeli WB, Zijlstra FRH, et al. Duurzame inzetbaarheid bij oudere werknemers, werk als waarde. Gedrag en Organisatie. 2011; 24(4):342-56.

22. Stone DL, Colella A. A model of factors affecting the treatment of disabled individuals in organizations. Acad Manage Rev. 1996;21(2):352-401. 
23. Scior K. Public awareness, attitudes and beliefs regarding intellectual disability: a systematic review. Res Dev Disabil. 2011; 32(6):2164-82.

24. Gewurtz R, Kirsh B. Disruption, disbelief and resistance: a metasynthesis of disability in the workplace. Work. 2009;34(1):33-44.

25. Kirsh B, Stergiou-Kita M, Gewurtz R, Dawson D, Krupa T, Lysaght R, et al. From margins to mainstream: what do we know about work integration for persons with brain injury, mental illness and intellectual disability? Work. 2009;32(4):391-405.

26. United Nations enable. Convention on the rights of persons with disabilities. United Nations. (2006); http://www.un.org/disabilities/ default.asp?navid=14\&pid=150. Accessed 19 Jun 2012.

27. US Department of Justice. The Americans with disabilities act of 1990. US Department of Justice. (1990); http://www.ada.gov/ pubs/ada.htm. Accessed 19 Jun 2012.

28. Administration for Children and Families. The developmental disabilities assistance and bill of rights act of 2000. US Department of Health and Human Services. (2000); http://www.acf.hhs. gov/programs/add/ddact/DDA.html. Accessed 19 Jun 2012.

29. Gates LB, Akabas SH, Oran-Sabia V. Relationship accommodations involving the work group: improving work prognosis for persons with mental health conditions. Psychiatr Rehabil J. 1998; 21(3):264-72.

30. Lau JTF, Cheung CK. Discriminatory attitudes to people with intellectual disability or mental health difficulty. Int Soc Work. 1999;42(4):431-44.

31. Cramm JM, Tebra N, Finkenflügel H. Colleagues' perception of supported employee performance. J Policy Pract Intell Disabil. 2008;5(4):269-75.

32. McLaughlin ME, Bell MP, Stringer DY. Stigma and acceptance of persons with disabilities-Understudied aspects of workforce diversity. Group Organ Manage. 2004;29(3):302-33.

33. Fishbein M, Ajzen I. Belief, attitude, intention, and behavior: an introduction to theory and research. Reading: Addison-Wesley; 1975.

34. Eagly AH, Chaiken S. The psychology of attitudes. Orlando: Harcourt Brace Jovanovich College Publishers; 1993.

35. Glaser BG, Strauss AL. The discovery of grounded theory: strategies for qualitative research. Chicago: Aldine Publishing Company; 1967.

36. Amick III BC, Habeck RV, Hunt A, Fossel AH, Chapin A, Keller $\mathrm{RB}$, et al. Measuring the impact of organizational behaviors on work disability prevention and management. J Occup Rehabil. 2000;10(1):21-38.

37. Angermeyer MC, Beck M, Dietrich S, Holzinger A. The stigma of mental illness: patients' anticipations and experiences. Int $\mathbf{J}$ Soc Psychiatr. 2004;50(2):153-62.

38. Banks B, Charleston S, Grossi T, Mank D. Workplace supports, job performance, and integration outcomes for people with psychiatric disabilities. Psychiatr Rehabil J. 2001;24(4): 389-96.

39. Bruyére SM, Erickson WA, VanLooy S. Comparative study of workplace policy and practices contributing to disability nondiscrimination. Rehabil Psychol. 2004;49(1):28-38.

40. Burge P, Ouellette-Kuntz H, Lysaght R. Public views on employment of people with intellectual disabilities. J Vocat Rehabil. 2007;26:29-37.

41. Butterworth J, Hagner D, Helm DT, Whelley TA. Workplace culture, social interactions, and supports for transition-age young adults. Ment Retard. 2000;38(4):342-53.

42. Chadsey JG, Sheldon DL, Horn JR, Bardeleben D, Cimera RE. Description of variables impacting successful and unsuccessful cases of social integration involving co-workers. J Vocat Rehabil. 1999;12(2):103-11.

43. Colella A, DeNisi AS, Varma A. The impact of ratee's disability on performance judgments and choice as partner: the role of disability-job fit stereotypes and interdependence of rewards. J Appl Psychol. 1998;83(1):102-11.

44. Colella A, Varma A. Disability-job fit stereotypes and the evaluation of persons with disabilities at work. J Occup Rehabil. 1999;9(2):79-95.

45. Colella A, Varma A. The impact of subordinate disability on leader-member exchange relationships. Acad Manage J. 2001;44(2):304-15.

46. Fillary R, Pernice R. Social inclusion in workplaces where people with intellectual disabilities are employed: implications for supported employment professionals. Int J Rehabil Res. 2006;29(1): $31-6$.

47. García MF, Paetzold RL, Colella A. The relationship between personality and peers' judgments of the appropriateness of accommodations for individuals with disabilities. J Appl Soc Psychol. 2005;35(7):1418-39.

48. Gilbride D, Stensrud R, Vandergoot D, Golden K. Identification of the characteristics of work environments and employers open to hiring and accommodating people with disabilities. Rehabil Couns Bull. 2003;46(3):130-7.

49. Habeck R, Hunt A, Rachel CH, Kregel J, Chan F. Employee retention and integrated disability management practices as demand side factors. J Occup Rehabil. 2010;20(4):443-55.

50. Hand C, Tryssenaar J. Small business employers' views on hiring individuals with mental illness. Psychiatr Rehabil J. 2006;29(3): 166-73.

51. Harlan SL, Robert PM. The social construction of disability in organizations - why employers resist reasonable accommodation. Work Occup. 1998;25(4):397-435.

52. Hartnett HP, Stuart H, Thurman H, Loy B, Batiste LC. Employers' perceptions of the benefits of workplace accommodations: reasons to hire, retain and promote people with disabilities. J Vocat Rehabil. 2011;34(1):17-23.

53. Henry D, Keys C, Balcazar F, Jopp D. Attitudes of community living staff members toward persons with mental retardation, mental illness, and dual diagnosis. Ment Retard. 1996;34(6): 367-79.

54. Henry DB, Duvdevany I, Keys CB, Balcazar FE. Attitudes of American and Israeli staff toward people with intellectual disabilities. Ment Retard. 2004;42(1):26-36.

55. Honey A. The impact of mental illness on employment: consumers' perspectives. Work. 2003;20(3):267-76.

56. Horner-Johnson W, Keys C, Henry D, Yamaki K, Oi F, Watanabe $\mathrm{K}$, et al. Attitudes of Japanese students toward people with intellectual disability. J Intell Disabil Res. 2002;46:365-78.

57. Jones J, Ouellette-Kuntz H, Vilela T, Brown H. Attitudes of community developmental services agency staff toward issues of inclusion for individuals with intellectual disabilities. J Policy Pract Intell Disabil. 2008;5(4):219-26.

58. Kaye H, Jans L, Jones E. Why don't employers hire and retain workers with disabilities? J Occup Rehabil. 2011;21(4):526-36.

59. Kulkarni M, Lengnick-Hall ML. Socialization of people with disabilities in the workplace. Hum Resource Manage. 2011; 50(4):521-40.

60. Martz E. Facilitating inclusive employment: an examination of the accommodations for and the barriers to employment for Russians with disabilities. Int J Rehabil Res. 2007;30(4):321-6.

61. Morgan RL, Alexander M. The employer's perception: employment of individuals with developmental disabilities. J Vocat Rehabil. 2005;23:39-49.

62. Novak J, Jo Feyes K, Christensen KA. Application of intergroup contact theory to the integrated workplace: setting the stage for inclusion. J Vocat Rehabil. 2011;35:211-26.

63. Ouellette-Kuntz H, Burge P, Henry DB, Bradley EA, Leichner P. Attitudes of senior psychiatry residents toward persons with intellectual disabilities. Can J Psychiat. 2003;48(8):538-45. 
64. Paetzold RL, García MF, Colella A, Ren LR, del Carmen Triana M, Ziebro M. Perceptions of people with disabilities: when is accommodation fair? Basic Appl Soc Psych. 2008;30(1):27-35.

65. Popovich PM, Scherbaum CA, Scherbaum KL, Polinko N. The assessment of attitudes toward individuals with disabilities in the workplace. J Psychol. 2003;137(2):163-77.

66. Rollins AL, Bond GR, Jones AM, Kukla M, Collins LA. Workplace social networks and their relationship with job outcomes and other employment characteristics for people with severe mental illness. J Vocat Rehabil. 2011;35:243-52.

67. Rollins AL, Mueser KT, Bond GR, Becker DR. Social relationships at work: does the employment model make a difference? Psychiatr Rehabil J. 2002;26(1):51-61.

68. Ross GF. Ethics, trust and expectations regarding the treatment of disabled staff within a tourism/hospitality industry context. Int $\mathbf{J}$ Hosp Manag. 2004;23(5):523-44.

69. Russinova Z, Griffin S, Bloch P, Wewiorski NJ, Rosoklija I. Workplace prejudice and discrimination toward individuals with mental illnesses. J Vocat Rehabil. 2011;35:227-41.

70. Scheid TL. Stigma as a barrier to employment: mental disability and the Americans with disabilities act. Int $\mathrm{J}$ Law Psychiat. 2005;28(6):670-90.

71. Scherbaum CA, Scherbaum KL, Popovich PM. Predicting jobrelated expectancies and affective reactions to employees with disabilities from previous work experience. J Appl Soc Psychol. 2005;35(5):889-904.

72. Schur L, Kruse D, Blasi J, Blanck P. Is disability disabling in all workplaces? Workplace disparities and corporate culture. Ind Relat. 2009;48(3):381-410.
73. Schwartz C, Armony-Sivan R. Students' attitudes to the inclusion of people with disabilities in the community. Disabil Soc. 2001;16(3):403-13.

74. Solovieva TI, Dowler DL, Walls RT. Employer benefits from making workplace accommodations. Disabil Health J. 2011;4(1): $39-45$.

75. Varekamp I, van Dijk FJH. Workplace problems and solutions for employees with chronic diseases. Occup Med. 2010;60(4):287-93.

76. Vilà M, Pallisera M, Fullana J. Work integration of people with disabilities in the regular labour market: what can we do to improve these processes? J Intellec Dev Dis. 2007;32(1):10-8.

77. Westmorland MG, Williams RM, Amick III BC, Shannon H, Rasheed F. Disability management practices in Ontario workplaces: employees' perceptions. Disabil Rehabil. 2005;27(14):825-35.

78. Williams-Whitt K. Impediments to disability accommodation. Ind Relat. 2007;62(3):405-32.

79. Yazbeck M, McVilly K, Parmenter T. Attitudes toward people with intellectual disability (ID): an Australian perspective. J Disabil Policy Stud. (2004); doi:10.1177/10442073040150020401.

80. Jiranek D, Kirby N. The job satisfaction and/or psychological well being of young adults with an intellectual disability and nondisabled young adults in either sheltered employment, competitive employment or unemployment. Aust NZ J Dev Disabil. 1990;16(2):133-48.

81. Griffin DK, Rosenberg H, Cheyney W, Greenberg B. A comparison of self-esteem and job satisfaction of adults with mild mental retardation in sheltered workshops and supported employment. Educ Train Ment Ret. 1996;31(2):142-50. 